\title{
Media Relations Humas Pemerintah Kota Bukittinggi (Studi Deskriptif mengenai Strategi Media Relations Humas Pemerintah Kota Bukittinggi dalam Membangun Hubungan Baik dengan Media Massa Lokal)
}

\author{
Dhira Mayasari, Susie Perbawasari, Heru Ryanto Budiana \\ Prodi Humas, Fikom Unpad, Jl. Raya Bandung-Sumedang Km. 21 Jatinangor \\ Email: heru.prodihumas@gmail.com
}

\begin{abstract}
ABSTRAK
Media relations juga merupakan salah satu tugas pokok fungsi Bagian Hubungan Masyarakat (Humas) Sekretariat Daerah Kota Bukittinggi yang merupakan Satuan Kerja Perangkat Daerah (SKPD) Pemerintah Kota Bukittinggi yang tercantum dalam Tugas Pokok dan Fungsi Bagian Hubungan Masyarakat Setda Pemko Bukittinggi Pasal 39 ayat (1).

Penelitian ini bertujuan untuk menggambarkan strategi media relations Humas Pemerintah Kota Bukittinggi dalam membangun hubungan yang baik dengan media massa. Penelitian ini menggunakan metode deskriptif dengan pendekatan kualitatif. Teknik pengumpulan data menggunakan observasi, wawancara, dan studi dokumen. Teknik validitas data menggunakan triangulasi data.

Hasil penelitian menunjukkan bahwa Humas Pemerintah Kota Bukittinggi mengelola relasi, mengembangkan strategi, dan mengembangkan jaringan dalam melakukan media relations. Kesimpulan penelitian ini bahwa Humas Pemerintah Kota Bukittinggi masih belum maksimal dalam membangun relasi, mengembangkan strategi, dan mengembangkan jaringan. Saran bagi pihak Humas Pemerintah Kota Bukittinggi, dalam mengelola relasi sebaiknya lebih memahami kebutuhan media, dalam mengembangkan strategi sebaiknya mengadakan pelatihan dan pendidikan kehumasan yang berhubungan dengan media relations, dan dalam mengembangkan jaringan sebaiknya lebih aktif dalam organisasi Bakohumas.
\end{abstract}

Kata kunci: Media Relations, Public Relations, Strategi Media Relations

\begin{abstract}
Media relations is one of the main task and function of Public Relations Department at Secretariat of Bukittinggi City Government. Public relations department is one of the SKPD (Satuan Kerja Perangkat Daerah or Regional Instrument Work Unit) of Bukittinggi City Government as it is written in article 39 verse 1.

The purpose of this research is to elaborate media relations strategy of Bukittinggi Public Relations Department in establishing good relations with mass media. This research uses descriptive method with qualitative approach. Data collection technique used in this research are through observation, interview, and document; while using data validity technique of data triangulation.

Result of this research shows that Public Relations Department of Bukittinggi City Government in doing media relations work is in charge in managing relations, developing strategies, and establishing network. It is concluded that the effort being done has not reach an optimum level, which prompted some suggestions in term of strategic development and network establishment such as: initiating public relations workshop and education related to media relations, and more active in Bakohumas (Badan Koordinasi Hubungan Masyarakat or Coordination Body on Public Relations) to strengthen existing network.
\end{abstract}

Keywords: Media Relations, Public Relations, Media Relations Strategy 


\section{PENDAHULUAN}

Kota Bukittinggi adalah kota terbesar kedua di Provinsi Sumatera Barat, Indonesia. Kota ini tentunya mempunyai peranan penting dalam pemerintahan. Hal tersebut menuntut Kota Bukittinggi untuk selalu menempatkan posisinya secara tepat demi kepentingan masyarakat. Dalam UU KIP pasal 10 ayat (2) disebutkan bahwa badan publik wajib menyebarluaskan informasi publik dengan cara yang mudah dijangkau oleh masyarakat dan dalam bahasa yang mudah dipahami. Salah satu cara yang bisa dilakukan pemerintah dan badan publik guna mewujudkan apa yang diamanatkan undang-undang tersebut, adalah bekerjasama dan menjalin hubungan baik dengan media (media relations).

Pelaksanaan media relations juga merupakan salah satu tugas pokok fungsi Bagian Hubungan Masyarakat (Humas) Sekretariat Daerah Kota Bukittinggi yang merupakan Satuan Kerja Perangkat Daerah (SKPD) Pemerintah Kota Bukittinggi yang tercantum dalam Tugas Pokok dan Fungsi Bagian Hubungan Masyarakat Setda Pemko Bukittinggi Pasal 39 ayat (1), yaitu:

"Bagian Hubungan Masyarakat mempunyai tugas menyiapkan bahan pembinaan dan pengembangan hubungan masyarakat dalam rangka pemantapan pelaksanaan kebijakan

Pemerintah daerah yang
berhubungan dengan data dan
informasi, pemberitaan mass media
dan hubungan antar lembaga.”1

Terdapat lima kegiatan pada tahun 2014 yang berkaitan dengan kerjasama media, diantaranya penyebaran informasi pembangunan daerah melalui media cetak; promosi dan sharing informasi melalui mass media, profil dan dokumentasi; penyebarluasan informasi yang bersifat penyuluhan bagi masyarakat melalui media elektronik dan mobil unit; penunjang pers dan kehumasan; dan dialog selamat pagi walikota.

Program kerjasama dengan media massa yang dilakukan ternyata tidak menjamin pengelolaan hubungan media itu sendiri berjalan lancar. Terlihat dari kualitas dan kuantitas informasi tentang Pemerintah Kota Bukittinggi yang diberitakan oleh media massa lokal. Berita-berita yang muncul, sering kali kurang berimbang dan terkesan menyudutkan pemerintah. Sementara kegiatan, program dan kebijakan pemerintah daerah yang seharusnya diketahui oleh masyarakat, tidak jarang luput dari pemberitaan media. Hal tersebut tentunya akan berimbas pada

\footnotetext{
1 Tugas Pokok dan Fungsi Bagian Humas Sekretariat Daerah Kota Bukittinggi yang ditetapkan melalui Peraturan Daerah Kota Bukittinggi No 13 Tahun 2009.
} 
buruknya pandangan publik terhadap pemerintah kota Bukittinggi. Sementara dalam penyelenggaraan roda pemerintahan, pemerintah sangat membutuhkan dukungan masyarakat.

Pada sisi lain, media massa lokal juga memiliki pandangan negatif terhadap Pemko Bukittinggi. Bagian humas dan Pemko Bukittinggi tidak terbuka kepada media. Dalam memberikan informasi, humas cenderung menutupi kejadian sebenarnya dan mencari alasan yang terkesan mengada-ada.

Humas melakukan berbagai upaya dalam menanggulangi permasalahan tersebut agar hubungan humas dengan media terjalin dengan baik, yaitu dari segi pemberitaan dan strategi transparansi, akan tetapi tampaknya humas masih kurang memahami kebutuhan media, yaitu dalam memberikan pelayanan kepada wartawan media massa. Salah satunya dalam hal pemberian fasilitas kepada wartawan, dan humas juga kurang terbuka dalam memberikan informasi jika itu terkait dengan kesalahan yang dilakukan oleh Pemerintah Kota Bukittinggi. Tidak hanya soal kebutuhan media, humas juga masih belum optimal dalam memberikan pelayanan kepada wartawan terkait soal informasi. Hal ini disebabkan oleh kurangnya koordinasi humas dengan bagian-bagian lain dalam instansi sehingga wartawan selalu kurang update mengenai kegiatan-kegiatan SKPD-SKPD lain yang seharusnya bisa diliput wartawan dan dipublikasikan.

Berdasar uraian tersebut, penelitian ini akan mengkaji bagaimana startegi media relations Humas Setda Pemkot Bukittinggi dalam membangun hubungan yang baik dengan media massa lokal.

\section{TINJAUAN PUSTAKA}

\section{Humas Pemerintahan}

Penyelenggaraan public relations atau humas di lingkungan instansi pemerintahan diatur dalam Peraturan Menteri Negara Pendayagunaan Aparatur Negara Nomor Per/12/M.PAN/08/Tahun 2007 tentang Pedoman Umum Hubungan Masyarakat di Lingkungan Instansi Pemerintah. Dalam peraturan tersebut, humas pemerintahan mempunyai definisi sebagai lembaga humas dan/atau praktisi humas pemerintah yang melakukan fungsi manajemen dalam bidang komunikasi dan informasi yang persuasive dan komunikatif untuk menciptakan hubungan yang harmonis dengan publiknya melalui berbagai sarana kehumasan dalam rangka menciptakan citra yang positif instansi pemerintah.

\section{Strategi Media Relations (Hubungan Media) Mengelola Relasi}

Membangun relasi yang baik dengan media massa dan wartawan adalah 
hal yang penting untuk diingat adalah hubungan antara dua profesi atau bidang tugas yang saling membutuhkan. Hubungan tersebut dapat terjalin dengan baik tentu saja mesti ada komunikasi yang cukup intens di antara kedua belah pihak yang berkenaan dengan tugas-tugas pokok masing-masing. Sarana-sarana yang memungkinkan kedua belah pihak bisa berkomunikasi dikembangkan. Misalnya, yang paling sederhana adalah memberikan kartu nama yang berisi nomor telepon kantor, nomor telepon seluler, nomor telepon rumah dan alamat e-mail. Hal ini akan memudahkan pihak media menghubungi kita manakala membutuhkan informasi. (Iriantara, 2008: 83).

Humas dalam menyusun daftar media, biasanya diperhitungkan aspekaspek sebagai berikut:

1. Jenis khalayak media (pembaca/pendengar/pemirsa);

2. Cakupan media (tiras/jumlah pemirsa/jumlah pendengar secara geografis);

3. Level media (nasional/regional/lokal). (Iriantara, 2008: 86-87).

Membangun relasi antara organisasi dengan media massa pun bisa dibangun berdasarkan hubungan antara manusia. PRO adalah manusia dan wartawan yang mewakili media massa pun manusia. Hubungan antarmanusia yang sifatnya pribadi dan seolah lepas dari hubungan tugas atau hubungan kerja bisa dibangun. Sentuhan kemanusiaan ini umumnya dilakukan untuk membangun relasi yang lebih akrab. Dengan demikian, pada dasarnya membangun dan mengelola relasi dengan media massa bisa dibangun melalui dua bentuk relasi, yakni relasi tugas dan relasi pribadi. (Iriantara, 2008: 88).

\section{Mengembangkan Strategi}

Strategi pada dasarnya merupakan kebijakan untuk mencapai tujuan yang kemudian dijabarkan ke dalam sejumlah taktik untuk pencapaian tujuan yang sudah ditetapkan. Ada pula yang menyebut strategi sebagai rencana dan member penjelasan atas metode yang dipakai untuk mencapai tujuan yang sudah ditetapkan. Karena itu, maka strategi media relations merupakan sekumpulan kebijakan dan taktik yang sudah ditetapkan untuk mencapai tujuan kegiatan media relations khususnya dan PR pada umumnya yang tentunya diacukan pada tujuan organisasi. Tujuan kegiatan PR merupakan penjabaran dari tujuan yang hendak dicapai organisasi, sehingga tujuan media relations pun akan terkait dengan tujuan organisasi tersebut. (Iriantara, 2008: 8990). 


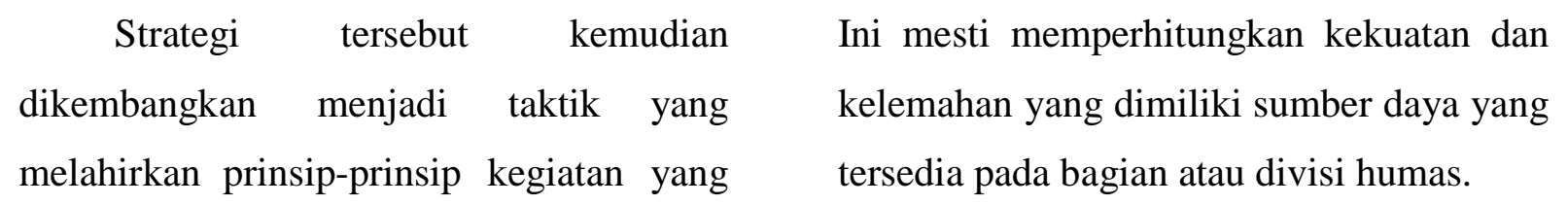

bisa dilakukan untuk mencapai tujuan organisasi. Taktik tidak lain merupakan perincian cara untuk mencapai tujuan yang sudah ditetapkan.

Taktik-taktik yang dikembangkan dari strategi sebuah organisasi untuk mencapai tujuannya meliputi:

1) Terus-menerus mengembangkan materi PR untuk media massa;

2) Menggunakan berbagai media yang ada untuk menyampaikan pesan kepada public;

3) Membangun dan memelihara kontak dengan media massa;

4) Memosisikan organisasi sebagai sumber informasi handal untuk media massa dalam bidang tertentu, misalnya untuk produk ramah-lingkungan;

5) Memosisikan pemimpin organisasi sebagai juru-bicara atau ketua dalam asosiasi profesi atau asosiasi perusahaan sejenis;

6) Selalu berkoordinasi dengan bagian-bagian lain dalam perusahaan sehingga selalu mendapatkan informasi mutakhir. (Iriantara, 2008: 91).

Dalam mengembangkan strategi, ada hal yang harus diperhatikan, yaitu ketersediaan sumber daya pada organisasi.

\section{Mengembangkan Jaringan}

Pengembangan jaringan merupakan aspek pokok dalam media relations organisasi. Bagaimana mengembangkan jaringan tersebut, pada dasarnya mempertanyakan posisi kita dalam system komunikasi yang ada pada masyarakat. Banyak yang menyebutkan, salah satu cara untuk mengembangkan jaringan tersebut adalah memasuki organisasi-organisasi profesi atau memiliki kontak dengan organisasi profesi. (Iriantara, 2005: 95).

$$
\text { Melalui organisasi profesi }
$$
kehumasan itulah kita bisa mendapatkan infromasi, memperluas relasi, atau memungkinkan kita saling tukas-menukar pengalaman. Berkaitan dengan media relations, memiliki hubungan yang baik dengan organisasi profesi kewartawanan tentu sangat penting guna memperluas jaringan kita dengan media massa. (Iriantara 2008: 95).

Soal jaringan itu pulalah yang ditegaskan Agoglia (2003). Pentingnya mengembangkan relasi dengan para wartawan. Relasi dengan wartawan itu akan membuka peluang bagi kita dijadikan sebagai sumber berita. Hal inilah yang pada gilirannya akan membuat 
pada kegiatan-kegiatan dalam program media relations akhirnya mendapatkan perhatian dari media massa. Intinya, dalam pandangan Agoglia, membuka jaringan relasi dengan media massa itu adalah untuk melapangkan jalan mendapatkan perhatian media massa.

\section{METODE PENELITIAN}

Penelitian ini menggunakan paradigma positivistik dengan metode penelitian deskriptif dengan menggunakan jenis data kualitatif. Moleong (2004:11), menjelaskan bahwa dalam metode deskriptif, data yang dikumpulkan adalah berupa kata-kata, gambar, dan bukan angka-angka. Hal itu disebabkan oleh adanya penerapan metode kualitatif, selain itu, semua yang dikumpulkan berkemungkinan menjadi kunci terhadap apa yang sudah diteliti. Oleh karena itu, peneliti hanya memaparkan dan menggambarkan situasi yang ada di lapangan sesuai keadaan yang ada agar menghasilkan data yang objektif. Pada penelitian ini, data dikumpulkan melalui kegiatan wawancara semiterstruktur dengan menggunakan pedoman wawancara kepada key informant yang memenuhi kriteria peneliti, observasi partisipan pasif dan studi dokumen. Teknik validitas data yang peneliti gunakan adalah triangulasi data.

\section{HASIL DAN PEMBAHASAN \\ Strategi Media Relations Humas Pemerintah Kota Bukittinggi dalam Mengelola Relasi}

Membangun relasi yang baik dengan media massa dan wartawan hal yang penting untuk diingat adalah hubungan antara dua profesi atau bidang tugas yang saling membutuhkan. Membangun relasi antara organisasi dengan media massa pun bisa dibangun berdasarkan hubungan antara manusia. PRO adalah manusia dan wartawan yang mewakili media massa pun manusia. Hubungan antarmanusia yang sifatnya pribadi dan seolah lepas dari hubungan tugas atau hubungan kerja bisa dibangun. Sentuhan kemanusiaan ini umumnya dilakukan untuk membangun relasi yang lebih akrab. Dengan demikian, pada dasarnya membangun dan mengelola relasi dengan media massa bisa dibangun melalui dua bentuk relasi, yakni relasi tugas dan relasi pribadi. (Iriantara, 2008: 88).

Terkait relasi tugas, Humas mengadakan kerjasama dengan media massa lokal, baik media cetak maupun elektronik, yang sifatnya ada ikatan MOU antara Pemerintah Kota dengan media. Jenis-jenis kegiatan media relations yang dilakukan oleh Humas Pemerintah Kota Bukittinggi, diantaranya:

\section{Penyebaran}

informasi pembangunan daerah melalui 
media cetak.

Kegiatan ini dilakukan dalam bentuk berlangganan dengan 31 (tiga puluh satu) media cetak (harian dan mingguan) lokal dan bantuan transportasi liputan lapangan.

2. Promosi dan sharing informasi melalui mass media, profil, dan dokumentasi.

Kegiatan ini meliputi liputan khusus media TV, pariwara atau laporan khusus media cetak harian dan mingguan, promosi atau liputan pada halaman satu media cetak harian dan rekaman serta penyiaran pidato untuk pimpinan daerah.

3. Kegiatan penyebarluasan informasi yang bersifat penyuluhan bagi masyarakat melalui media elektronik dan mobil unit.

Kerjasama dilakukan dengan media eletronik lokal seperti televisi lokal dan radio lokal, dalam bentuk belanja jasa pengumuman atau publikasi.

4. Jumpa Pers (Penunjang Pers dan Kehumasan)

Guna menjalin komunikasi langsung antara pemerintah kota dengan media massa lokal terutama wartawan, bagian humas juga menyelenggaran jumpa pers yang terangkum dalam kegiatan penunjang pers dan kehumasan.

5. Kegiatan Dialog Selamat Pagi Walikota

Kegiatan Dialog Selamat Pagi Walikota yaitu dialog interaktif dengan tema yang telah ditentukan oleh Pemerintah Kota Bukittinggi dengan masyarakat melalui sambungan radio secara langsung.

Kegiatan media relations tersebut agar terjalin dengan baik, Kriyantono (2008: 83-89) menjelaskan bahwa humas harus memahami kebutuhan media, beberapa tips yang bisa dilakukan PR untuk memahami kebutuhan media, yaitu:

1) Selalu menyampaikan informasi secara jujur.

Terkadang humas tertutup dalam memberikan informasi jika itu terkait dengan adanya kesalahan-kesalahan yang dilakukan oleh Walikota.

2) Penuhi janji Anda

Peranan Humas Pemerintah Kota Bukittinggi sangat membantu wartawan dalam mendapatkan sebuah informasi yang dibutuhkannya. Humas selalu bersedia dan cepat 
tanggap ketika kita

membutuhkan informasi terkait yang ditanyakan.

3) Mencerdaskan pers

Kepala Bagian Humas Pemko Bukittinggi, Yulman, S.IP, menyadari bahwa tidak semua wartawan yang paham dengan jurnalistik. Karena tidak semua wartawan yang paham dengan apa itu jurnalistik, bagaimana cara penulisan berita, karena mereka lebih banyak mengambil release dari humas.

4) Melayani pekerjaan media

Untuk materi, humas Pemko Bukittinggi aktif dalam membagikan informasi dalam bentuk press release kepada masing-masing e-mail wartawan mengenai kegiatan-kegiatan Pemko Bukittinggi yang nantinya diolah oleh wartawan untuk dipublikasikan di media. Namun, untuk fasilitas pendukung masih minim. Humas Pemerintah Kota Bukittinggi menyediakan ruangan khusus bagi para wartawan agar para wartawan merasa nyaman ketika mereka berada di Humas Pemerintah Kota Bukittinggi. Namun, untuk persediaan fasilitas dari press room itu sendiri masih belum maksimal. Hal ini diungkapkan oleh Kepala Bagian Humas bahwa untuk press room ini sendiri masih kurang dalam hal instrumennya, harusnya ada computer dan meja tulis. Namun saat ini belum ada komputer.

Sedangkan untuk membangun relasi pribadi, humas dengan tetap menjaga silaturrahmi dengan media massa lokal. Secara kekeluargaan mendatangi media untuk lebih mendekatkan diri. Juga duduk-duduk bersama sekedar coffee morning untuk menjalin silaturrahmi dengan wartawan, dan studi banding. Bagian Humas tidak memiliki formula atau pola khusus dalam membangun hubungan personal dengan media, namun itu dilakukan dengan kemampuan masing-masing staf. Walaupun tidak ada kegiatan yang akan diberitakan, tetapi wartawan tetap sering main dan sering berkunjung ke kantor humas. Menjalin hubungan pertemanan yang baik tidak saja tahu dengan media, tetapi juga tahu dan kenal dekat dengan wartawannya, tahu keluarganya, tahu latar belakangnya, sehingga hubungan komunikasi lebih baik.

Humas dalam menyusun daftar media, biasanya diperhitungkan aspekaspek sebagai berikut: 
1. Jenis khalayak media (pembaca/pendengar/pemirsa)

2. Cakupan media (tiras/jumlah pemirsa/jumlah pendengar secara geografis)

3. Level media (nasional/regional/lokal). (Iriantara, 2008: 86-87)

Humas Pemerintah Kota Bukittinggi memiliki daftar media sehingga petugas kehumasan dapat dengan mudah menghubungi wartawan untuk memberikan informasi/berita. Di dalam daftar media terdapat nama media, nama redaksinya, nama wartawan yang bertugas di daerah tersebut, alamat redaksi, berikut contact person dan alamat e-mail masing-masing. Begitu juga sebaliknya, bagi wartawan yang butuh informasi kepada SKPD terkait, maka dapat menghubungi petugas kehumasan dari SKPD terkait.

Walaupun humas sudah membuat daftar media tersebut, namun humas tidak mengelompokkan daftar media sesuai dengan aspek-aspek seperti yang dijelaskan di dalam buku Iriantara tersebut. Humas menyamakan semua daftar media, tidak tidak memperhitungkan aspek-aspek seperti jenis khalayak media, cakupan media, dan level medianya.

\section{Strategi Media Relations Humas Pemerintah Kota Bukittinggi dalam Mengembangkan Strategi} Iriantara (2008:

89-90) mengemukakan bahwa strategi pada dasarnya merupakan kebijakan untuk mencapai tujuan yang kemudian dijabarkan ke dalam sejumlah taktik untuk pencapaian tujuan yang sudah ditetapkan. Taktik-taktik yang dikembangkan dari strategi sebuah organisasi untuk mencapai tujuannya meliputi:

1. Terus-menerus mengembangkan materi PR untuk media massa

Humas Pemerintah Kota Bukittinggi melakukan penambahan materi untuk media massa lokal di dalam program media relations. Penambahan materi yang dibuat oleh Humas Pemerintah Kota Bukittinggi yaitu dalam kegiatan peliputan. Humas Pemerintah Kota Bukittinggi selalu mengikutsertakan para wartawan dalam kegiatan peliputan yang ditujukan untuk meliput kegiatankegiatan yang dilakukan oleh Walikota Bukittinggi dan pejabatpejabat Pemerintah Kota Bukittinggi lainnya. Pada kegiatan peliputan biasanya para wartawan hanya meliput kegiatan Walikota dan pejabat pemerintah, dimana pada akhir acara Walikota dan 
pejabat Pemerintah Kota akan memberikan keterangan secara singkat mengenai kegiatan yang dilakukannya tersebut. Namun saat ini, para wartawan tidak hanya meliput kegiatan Walikota dan pejabat Pemerintah Kota saja, melainkan juga dapat melakukan wawancara eksklusif kepada Walikota atau pejabat Pemerintah Kota setelah kegiatan itu berlangsung.

2. Menggunakan berbagai media yang ada untuk menyampaikan pesan kepada publik.

Humas Pemerintah Kota media eksternal yang terdapat dalam daftar media, media tersebut adalah media cetak, media elektronik, dan media online. Tidak hanya dengan media eksternal, namun humas juga mengadakan media internal, untuk menyosialisasikan programprogram Pemerintah Daerah yang telah dilakukan selama ini dan hal ini akan tetap dilakukan humas dalam waktu sekitar sekali tiga bulan.

3. Membangun dan memelihara kontak dengan media massa

Humas Pemerintah Kota Bukittinggi juga membangun dan memelihara kontak dengan media massa lokal. Humas melakukannya melalui pertemuan-pertemuan dengan pihak media terutama wartawan, menfasilitasi media, kerjasama dengan media dalam bidang publikasi atau iklan, dan juga memberi informasi kepada media terkait kegiatan-kegiatan Pemerintah Kota Bukittinggi.

4. Memosisikan organisasi sebagai sumber informasi handal untuk media massa dan memosisikan pemimpin organisasi sebagai jurubicara atau ketua dalam asosiasi profesi atau asosiasi perusahaan sejenis.

Penyampaian informasi-informasi yang dapat berupa kebijakan, program dan kegiatan-kegiatan dari Pemerintah Kota Bukittinggi, haruslah disampaikan oleh narasumber yang handal. Humas Pemerintah Kota Bukittinggi selalu mengupayakan untuk menghadirkan Walikota sebagai narasumber dari penyampaian suatu informasi kepada media. Alasannya adalah Walikota merupakan pimpinan dari Pemerintah Kota Bukittinggi, yang membuat serta menjalankan kegiatan, kebijakan serta program di bidang pemerintahan. Jika Walikota 
berhalangan, maka yang menjadi sumber informasi diwakili oleh Kepala Bagian Humas.

Walikota menjadi narasumber apabila itu berkaitan dengan program-program dan kebijakankebijakan pemerintahan itu sendiri. Lain lagi halnya apabila kegiatankegiatan itu dilaksanakan oleh SKPD-SKPD lain, seperti Dinas Pendidikan, Dinas Pariwisata, Dinas Perhubungan, dll. Humas sampai saat ini belum pernah menghadirkan narasumber terkait kegiatan yang diselenggarakan. Wartawan kesulitan dalam mencari bahan dan mendapatkan informasi. Tetapi sampai saat ini, wartawan yang selalu mencari sendiri narasumber terkait. Kalau bukan Walikota yang mengadakan jumpa pers, wartawan tidak akan bertemu dengan narasumber atau SKPD lain yang dibutuhkan. Sebenarnya Kepala Dinas masing-masing SKPD yang bertugas untuk memberikan informasi kepada wartawan.

5. Selalu berkoordinasi dengan bagian-bagian lain dalam perusahaan sehingga selalu mendapatkan informasi yang mutakhir (Iriantara, 2008: 91)
Berkaitan dengan poin 4 (empat), untuk hal di atas terjadi karena tidak adanya koordinasi antara humas dengan SKPD-SKPD lain dalam memberikan informasi kepada wartawan. Sepanjang itu kegiatan yang berhubungan dengan Pemda selalu diberitahu, tetapi kalau SKPD lain tutup mulut ke humas. Ketika ditanya, mereka mengatakan kalau itu tugasnya humas, humas sendiri tidak tahu dengan kegiatan SKPD lain tersebut. Seharusnya semua SKPD itu bersinergi dengan humas, karena humas sebagai corong pemerintah dalam memberikan informasi kepada publik, jangan sampai ada informasi yang tidak diketahui oleh wartawan, namun kadangkadang SKPD lain menutup diri dan tidak memberikan informasi kepada humas.

Mengembangkan strategi humas terdapat bebrapa hal yang harus diperhatikan, yaitu ketersediaan sumber daya pada organisasi. Ini mesti memperhitungkan kekuatan dan kelemahan yang dimiliki sumber daya yang tersedia pada bagian atau divisi humas. Humas Pemerintah Kota Bukittinggi masih lemah dalam segi kualitas dan kuantitas sumber daya. Humas memiliki masalah dalam 
ketersediaan sumber daya manusia, dimana humas mengalami kekurangan tenaga, apalagi yang berlatar belakang pendidikan sesuai dengan bidangnya itu yang masih kurang dan masih minim. Di bagian humas sekarang ini yang berlatar belakang humas baru dua orang. Kepala Bagian Humas juga merasa bahwa humas sendiri masih lemah dari segi IT-nya.

\section{Strategi Media Relations Humas Pemerintah Kota Bukittinggi dalam Mengembangkan Jaringan}

Iriantara (2005: 95) mengemukakan bahwa pengembangan jaringan merupakan aspek pokok dalam media relations organisasi. Bagaimana mengembangkan jaringan tersebut, pada dasarnya mempertanyakan posisi kita dalam system komunikasi yang ada pada masyarakat. Banyak yang menyebutkan, salah satu cara untuk mengembangkan jaringan tersebut adalah memasuki organisasi-organisasi profesi atau memiliki kontak dengan organisasi profesi.

"Melalui organisasi profesi kehumasan itulah kita bisa mendapatkan infromasi, memperluas relasi, atau memungkinkan kita saling tukasmenukar pengalaman. Berkaitan dengan media relations, memiliki hubungan yang baik dengan organisasi profesi kewartawanan tentu sangat penting guna memperluas jaringan kita dengan media massa.” (Iriantara 2008: 95)

Humas Pemerintah Kota Bukittinggi melakukannya dengan memasuki organisasi kehumasan dan melakukan kontak dengan organisasi kewartawanan. Humas melakukan hubungan dengan Bakohumas (Badan Koordinasi Humas) sebagai salah satu organisasi kehumasan. Namun, untuk saat ini memang humas tidak banyak merasakan manfaatnya, kadang acaranya tidak terjadwal, terkadang juga kurang menyentuh ke masalah humas-humas daerah. Bako Humas tidak terlalu berdampak kepada Humas Kota Bukittinggi.

Soal jaringan itu pulalah yang ditegaskan Agoglia (2003). Pentingnya mengembangkan relasi dengan para wartawan. Relasi dengan wartawan itu akan membuka peluang bagi kita dijadikan sebagai sumber berita. Hal inilah yang pada gilirannya akan membuat pada kegiatan-kegiatan dalam program media relations akhirnya mendapatkan perhatian dari media massa. Intinya, dalam pandangan Agoglia, membuka jaringan relasi dengan media massa itu adalah untuk melapangkan jalan mendapatkan perhatian media massa.

Humas juga melakukan hubungan dan koordinasi dengan organisasi kewartawanan. Terdapat cukup banyak komunitas atau persatuan wartawan di 
Kota Bukittinggi, diantaranya PWI, HIPI, KWRI, HJTI, Aliansi Wartawan Pemerhati Lingkungan, Komunitas Wartawan Pemerhati Pariwisata, dan lainlain.

\section{SIMPULAN DAN SARAN \\ Simpulan}

Kesimpulan dalam penelitian ini sebagai berikut:

1. Humas Setda Pemko Bukittinggi mengelola relasi dalam membangun hubungan yang baik dengan media massa masih belum maksimal. Hal ini dikarenakan humas masih minim dalam melayani kebutuhan media, dimana humas terkadang masih tertutup dalam memberikan informasi jika itu terkait dengan adanya kesalahankesalahan yang dilakukan oleh Walikota dan dalam melayani pekerjaan media, humas masih minim dalam menyediakan fasilitas untuk media. Serta, humas tidak mempunyai klasifikasi khusus dan tidak memperhitungkan aspek-aspek tertentu dalam menyusun daftar media, seperti jenis khalayak media, cakupan media, ataupun level media.

2. Humas Setda Pemko Bukittinggi mengembangkan taktik-taktik dari strategi dalam membangun hubungan yang baik dengan media massa masih belum efektif. Hal tersebut dikarenakan humas belum mengimplementasikan beberapa taktik dengan maksimal. Humas sampai saat ini belum menghadirkan narasumber yang handal terkait kegiatan yang diliput oleh wartawan. Juga, humas belum maksimal dalam berkoordinasi dengan SKPDSKPD lain dalam memberikan informasi kepada wartawan, sehingga membuat wartawan dan humas itu sendiri tidak update soal kegiatan-kegiatan SKPD lain. Dalam hal ketersediaan sumber daya, Humas juga menyadari bahwa mereka masih lemah dari segi kualitas maupun dari segi kuantitas.

3. Humas Setda Pemko Bukittinggi mengembangkan jaringan dalam membangun hubungan yang baik dengan media massa masih belum maksimal. Humas memperluas jaringan dengan bergabung organisasi kehumasan, yaitu Bakohumas (Badan Koordinasi Humas Pemerintah), namun tidak banyak merasakan 
manfaatnya. Serta, humas juga menjalin hubungan dengan organisasi kewartawanan yang ada di Kota Bukittinggi, namun kegiatannya belum secara rutin terlaksana.

\section{Saran}

Adapun saran yang ingin disampaikan peneliti adalah:

1. Mengelola relasi, humas sebaiknya lebih optimal dalam melayani kebutuhan media, dimana humas harus terbuka dalam memberikan informasi meskipun jika itu terkait dengan adanya kesalahan-kesalahan yang dilakukan oleh Walikota dan dalam melayani pekerjaan media, humas sebaiknya menyediakan fasilitas untuk media. Serta, humas sebaiknya mempunyai klasifikasi khusus dan memperhitungkan aspekaspek tertentu dalam menyusun daftar media, seperti jenis khalayak media, cakupan media, ataupun level media.

2. Mengembangkan taktik-taktik dari strategi, humas sebaiknya mengimplementasikan taktiktaktik dengan maksimal. Humas sebaiknya menghadirkan narasumber yang handal terkait kegiatan yang diliput oleh wartawan. Juga, humas seharusnya berkoordinasi dengan SKPDSKPD lain dalam memberikan informasi kepada wartawan, sehingga wartawan dan humas itu sendiri update soal kegiatan-kegiatan SKPD lain. Dalam hal ketersediaan sumber daya, humas sebaiknya mengadakan pendidikan dan pelatihan kehumasan untuk mengembangkan pengetahuan (knowledge), keterampilan (skills), dan kepribadian (personality) yang berhubungan dengan media relations. Pelatihan semacam ini sebaiknya dilakukan secara berkesinambungan.

3. Mengembangkan jaringan, humas hendaknya lebih aktif dalam organisasi kehumasan, yaitu Bakohumas (Badan Koordinasi Humas Pemerintah), dan menjalin hubungan dengan organisasi kewartawanan, agar humas mempunyai kemungkinan dan berpeluang untuk menjadi narasumber dalam kegiatan yang diselenggarakan oleh organisasi kewartawanan tersebut. 


\section{DAFTAR PUSTAKA}

Bungin, Burhan H.M. 2008. Penelitian Kualitatif: Komunikasi, Ekonomi, Kebijakan Publik, dan Ilmu Sosial. Jakarta: Kencana Prenada Media Group.

Bungin, Burhan H.M. 2009. Sosiologi Komunikasi: Teori, Paradigma, dan Diskursus Teknologi Komunikasi di Masyarakat. Jakarta: Prenada Media Group.

Iriantara, Yosal. 2008. Media Relations: Konsep, Pendekatan, dan Praktik. Bandung: Simbiosa Rekatama Media.

Kriyantono, Rachmat. 2008. PR Writing:

Teknik Produksi Media Public Relations dan Publisitas Korporat. Jakarta: Kencana.

Moleong, Lexy J. 2004. Metodologi Penelitian Kualitatif. Bandung: PT Remaja Rosdakarya.

\section{Sumber Lainnya:}

Dokumen Pelaksanaa Anggaran(DPA)
Sekretariat Daerah Kota Bukittinggi tahun 2016

Peraturan Menteri Dalam Negeri (Permendagri) nomor 13 tahun 2011 tentang pedoman pelaksanaan tugas Humas Pemerintah

Peraturan Menteri Pemberdayagunaan Aparatur Negara Nomor: Per/12/M.PAN/08/Tahun 2007 tentang Pedoman Umum Hubungan Masyarakat di Lingkungan Instansi Pemerintah.

Tugas Pokok dan Fungsi Bagian Humas Sekretariat Daerah Kota Bukittinggi yang ditetapkan melalui Peraturan Daerah Kota Bukittinggi No 13 Tahun 2009.

Undang - Undang No. 14 Tahun 2008 Tentang Keterbukaan Informasi Publik.

Jakarta : Penerbit Departemen Komunikasi dan Informatika Republik Indonesia. 